
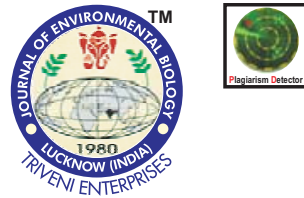

\title{
In vivo and in vitro toxicities of diethyl phthalate to flounder fish Paralichthys olivaceus and its gill cell line (FG cells)
}

Authors Info

Qin Xiao*, Daizong Li', Ran Guo', Lei Zheng', Xinlong An and Zhaochun Zeng ${ }^{1 *}$

${ }^{1}$ College of Ocean, Hebei Agricultural University, Qinhuangdao, 066 003, China

${ }^{2}$ College of Water Sciences, Beijing Normal University, Beijing, 100875, China

${ }^{*}$ Corresponding Author Email : qinxia0669@163.com

Key words

Diethyl phthalate

FG cell line

Paralichthys olivaceus

Toxicity

Publication Info

Paper received : 22.09.2016

Revised received : 19.04.2017

Re-revised received : 10.07.2017

Accepted : 21.08.2017

\section{Abstract}

Aim : Diethyl phthalate (DEP) as a plasticizer and softener of daily supplies, is immensely released in the aquatic environment. The study was undertaken in order to evaluate the toxicity of DEP using the marine flounder (Paralichthys olivaceus) and its gill cell line (FG cells) in vivo and in vitro.

Methodology : In vitro toxicity of DEP to FG cells was determined by neutral red uptake assay and methyl thiazolyl tetrazolium assay, along with observing the change of cellular morphology by a phase contrast inverted microscope. In vivo toxicity of DEP to flounder fish was evaluated by calculating the median lethal concentration $\left(\mathrm{LC}_{50}\right)$ in semi-static condition, observing the histopathological change in liver and kidney of flounders by staining with hematoxylin and eosin, and determining the biochemical parameters using an AEROSET automatic biochemical analyzer.

Results : DEP was acutely toxic to FG cells for $24 \mathrm{hr}$ in the range of $200 \mu \mathrm{g} \mathrm{ml}^{-1}-800 \mu \mathrm{g} \mathrm{ml}^{-1} .50 \%$ inhibition of cell proliferation $\left(\mathrm{IC}_{50}\right)$ of DEP for $24 \mathrm{hr}$ were $536.76 \mu \mathrm{g} \mathrm{ml}^{-1}$ and $573.84 \mu \mathrm{g} \mathrm{ml}^{-1}$ for NR uptake and MTT assay, respectively. Meanwhile, the FG cellular morphology was also negatively altered with EDP concentration increasing. In semi-static condition, the median lethal concentration $\left(\mathrm{LC}_{50}\right)$ of DEP for $96 \mathrm{hr}$ was $31.92 \mu \mathrm{g}$ $\mathrm{ml}^{-1}$ for Paralichthys olivaceus. DEP also caused various extents of histological structures damages in livers and kidneys when fish were exposed to 5,10 and $15 \mu \mathrm{g}$ $\mathrm{ml}^{-1}$ DEP, as evidenced by the necrosis of hepatocytes, the disorder of hepatic sinusoids, the degradation of tubular epithelial cells and multiple hemorrhages in kidneys. Meanwhile, the levels of alanine aminotransferase and lactate dehydrogenase were enhanced at the same concentration DEP treatments.

Interpretation : The study suggests that FG cell line can be a short term bioassay model for screening the potential toxicity of the pollutant, while living fish are a necessary model for studying DEP toxicity. This research will provide significant references for monitoring DEP pollution.

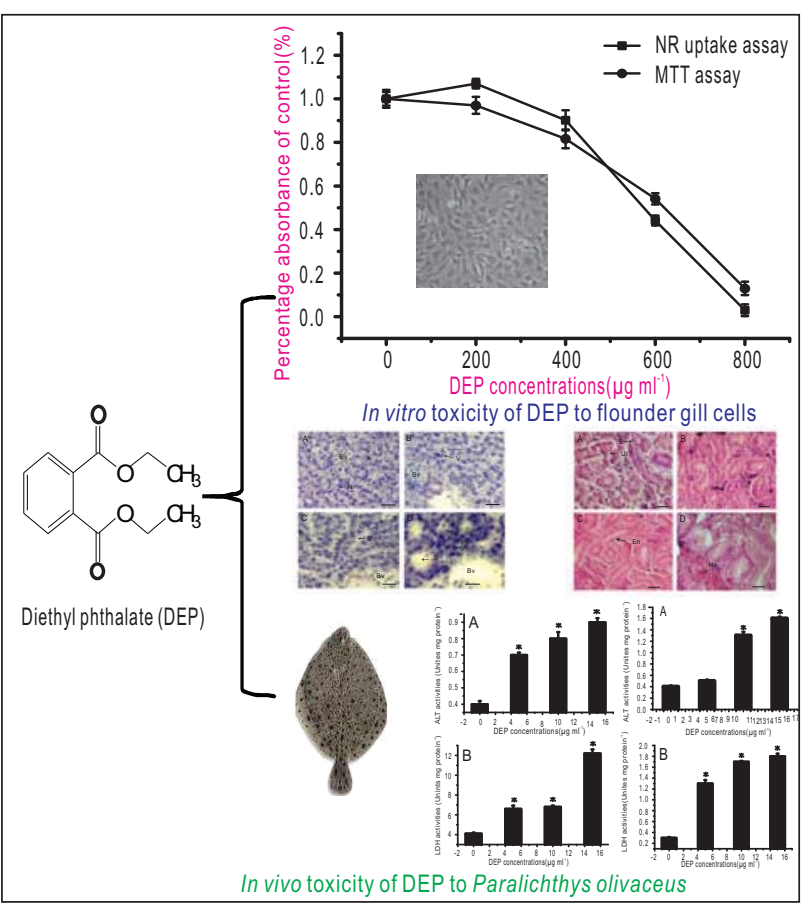




\section{Introduction}

Diethyl phthalate as a low molecular weight phthalate esters (PAEs), is extensively used as a plasticizer and softener in many products including automotive components, herbicides, toys, cosmetic formulations, medical treatment tubing, plastic packing films and so on (Page and Lacroix, 1995; Api, 2001). Since diethyl phthalate is not chemically bound to these polymer products, it can migrate readily from the plastics to the environment, especially the aquatic environment (Staples et al., 2000). It is frequently detectable worldwide in surface water as well as drinking water, leading to a significant exposure of the compound to organisms (Leitz et al., 2009). Its deleterious effects on human being have been reported, mainly interfering with the endocrine and immune systems (Giulivo et al., 2016). Diethyl phthalate toxicity has recently become a great environmental concern in aquatic ecosystems. The evaluation for DEP toxicity is foremost and should be done first.

The study of diethyl phthalate toxicity has been continued nearly 20 years. Previously, its acute toxicity was mainly determined using rats, guinea pigs, rabbits and chickens, and its lethal doses are more than $1 \mathrm{~g} \mathrm{~kg}^{-1}$ via oral or peritoneal administration (Api, 2001). Afterwards, some mammal cell lines, e.g. human breast carcinoma cell line (MCF-7) and Chinese hamster ovary $(\mathrm{CHO})$ cells, were also used to assess the impact of diethyl phthalate (Hong et al., 2005; Kumar et al., 2014, 2015). In aquatic environment, the diethyl phthalate toxicity is usually described by median lethal concentrations $\left(\mathrm{LC}_{50}\right)$ of fish, such as Cyprinus carpio (Barse et al., 2007), Cirrhina mrigala (Ghorpade et al., 2002) etc. In addition, fish (Pimephales promelis, Danio rerio) embryos have been also used to study diethyl phthalate toxicity (Mankidy et al., 2013; Kim et al., 2015). However, there are limited reports regarding the effect of diethyl phthalate toxicity on fish cell lines. Therefore, it is necessary to provide academic data about diethyl phthalate toxicity on fish cell lines.

The marine flounder, Paralichthys olivaceus, is an important cultured fish species in the Far East area including China, Japan and South Korea, has been successfully used to study the toxic effects of environmental pollutants (Nakayama et al., 2008; Kang et al., 2010; Vinay et al., 2014). Gill cell line (FG cells) of Paralichthys olivaceus, established from gill tissue (Tong et al., 1997), have also been widely applied in xenobiotic chemicals' cytotoxicity examinations (Xiao et al., 2007, 2011; Na et al., 2009; Pandey et al., 2014). Thus, the present aimed to study in vitro toxicity of diethyl phthalate and in vivo toxicity marine founder fish, and as well as compare the strengths and weaknesses of two kinds of bioassay models.

\section{Materials and Methods}

FG cells : The FG cell line was derived from the gill tissues of flounder (Paralichthys olivaceus) and maintained following to the method of Tong et al. (1997). Briefly, the FG cells were cultured in minimal Essential Medium (MEM; Gibco BRL, New York, USA) supplemented with $10 \%$ Bovine Calf Serum (BCS; Hyclone, Utah, USA), $100 \mathrm{IU} \mathrm{ml}^{-1}$ penicillin and $100 \mathrm{mg} \mathrm{ml}^{-1}$ streptomycin in plastic culture flasks (Corning, New York, USA) at $20^{\circ} \mathrm{C}$.

Fish maintenance : Marine flounders (Paralichthys olivaceus) $(8.9 \pm 0.25 \mathrm{~cm})$ were purchased from a local fish farm in Qinhuangdao, China. These fish were acclimatized in aerated natural seawater $\left(18-22^{\circ} \mathrm{C}\right)$ under ambient photo period in laboratory for at least 2 week before use. The fish were fed with live food twice a day.

DEP acute toxicity to FG cells in vitro : Cells were harvested

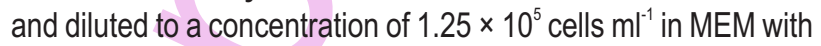
$10 \%$ BCS. The cell suspension was agitated and $200 \mu$ laliquots were added to each well of 96 -well tissue culture plates (Costar, Cambridge, MA, USA). Plates were incubated overnight at $20^{\circ} \mathrm{C}$ and next day the medium was removed. Based on the preliminary results, the cells were re-fed with medium containing 0 (solvent control), 100, 200, 400, 600 and $800 \mathrm{\mu g} \mathrm{ml}^{-1}$ diethyl phthalate. Then two endpoints for toxicity, i.e., NR uptake assay and MTT assay were determined after $24 \mathrm{hrs}$ diethyl phthalate exposure. Furthermore, the morphological changes of FG cells were also observed and photographed every day using a phase contrast inverted microscope (Nikon Eclipse TS-100, Japan).

Neutral red uptake assay, as described by Borenfreund and Puerner (1985), measured inhibition of cell growth, which was based on the absorbance of vital dye NR by living, but not by dead, cells. After 24 hrs diethyl phthalate exposure, the test medium was replaced by a $200 \mu$ medium containing $50 \mathrm{mg} \mathrm{ml}^{-1}$ neutral reel, which had been pre-incubated overnight at $20^{\circ} \mathrm{C}$ and filtrated prior to use to remove fine precipitates of dye crystals. After in situ incubation for $3 \mathrm{hrs}$ at $20^{\circ} \mathrm{C}$, the cells were rinsed with

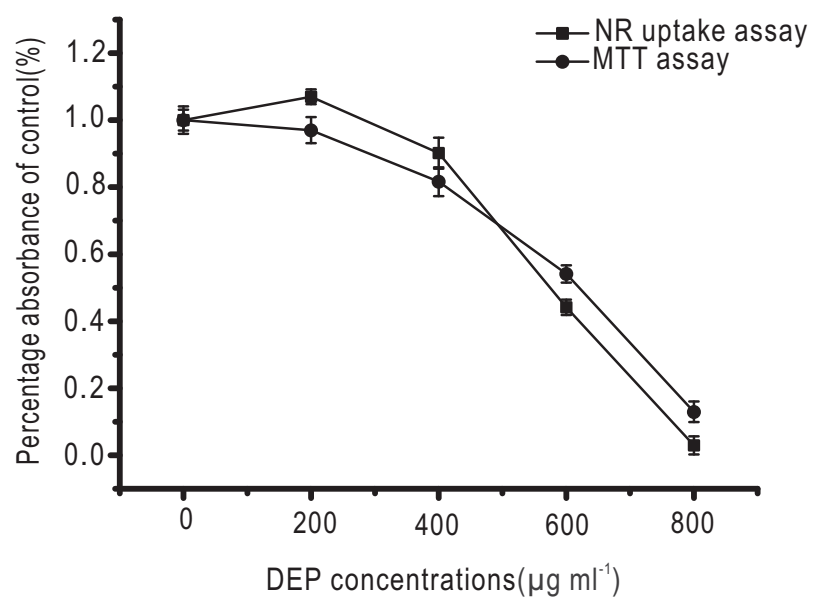

Fig. 1 : In vitro cytotoxicity of diethyl phthalate $(0,100,200,400,600,800$ $\mu \mathrm{g} \mathrm{ml}^{-1}$ ) to FG cells as justified by NR assay and MTT assay. The individual data points are expressed as the arithmetic mean percentage of control \pm S.E. $(n=3)$ 

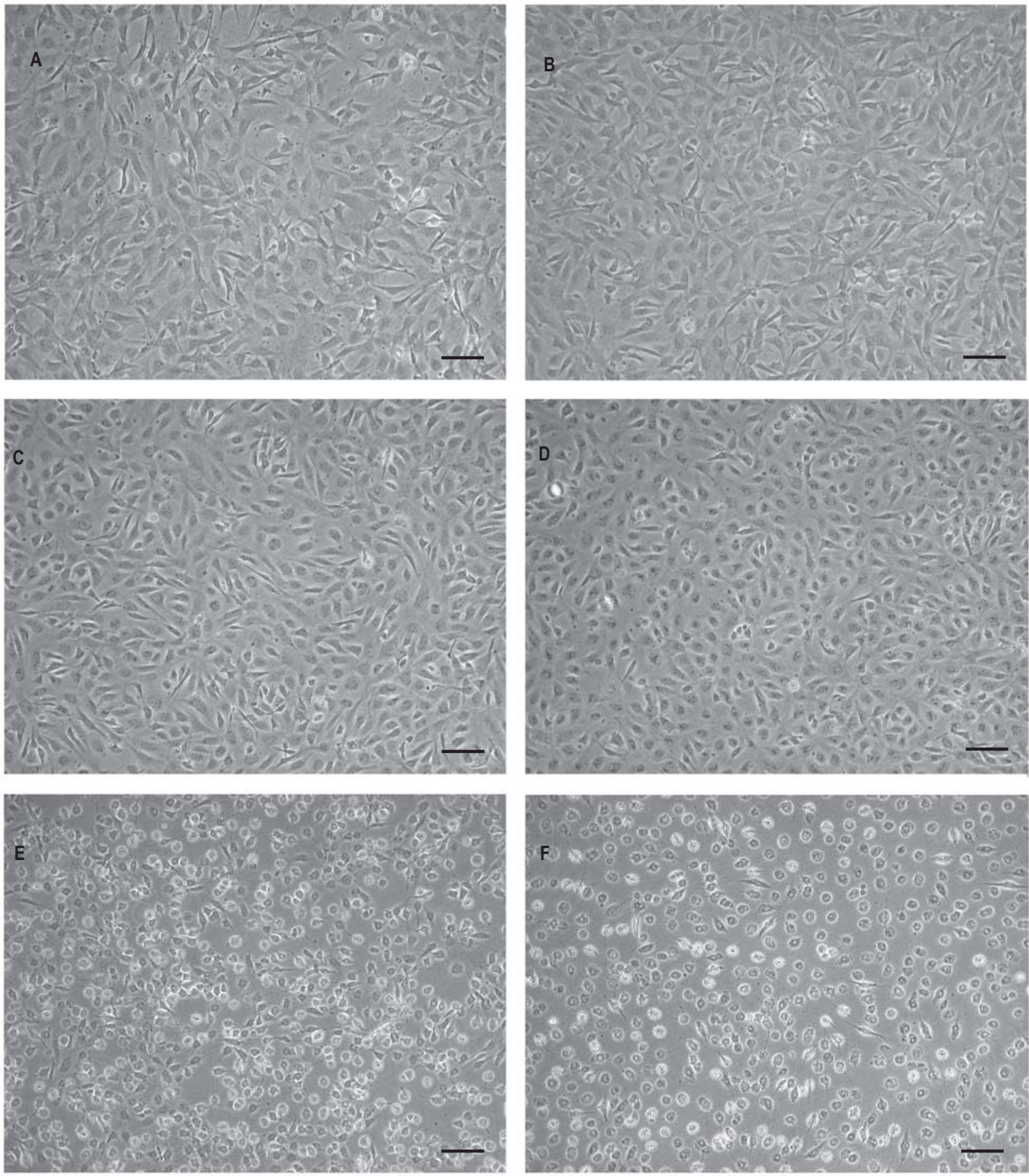

Fig. 2 : Morphological changes of FG cells exposed to varied concentrations of diethyl phthalate for $24 \mathrm{hrs}$. Panels A through F correspond to 0 (control),

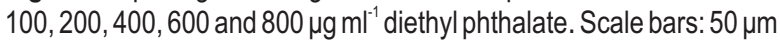

warmed phosphate-buffered saline and then destained with 200 $\mu l$ solution consisting of glacial acetic acid-96\% ethanol-water (1:50:49). After rapid agitation for 10 mins at room temperature, the absorbance of the solution in each well was measured at 540 $\mathrm{nm}$ with a microplate reader (Unico, CA, USA) and the $\mathrm{IC}_{50}$ value (concentration of test agent which causes a 50\% inhibition in cell proliferations) was determined.

MTT assay described by Borenfreund et al. (1988) was based on inhibition by chemical injury of the reduction yellow MTT 

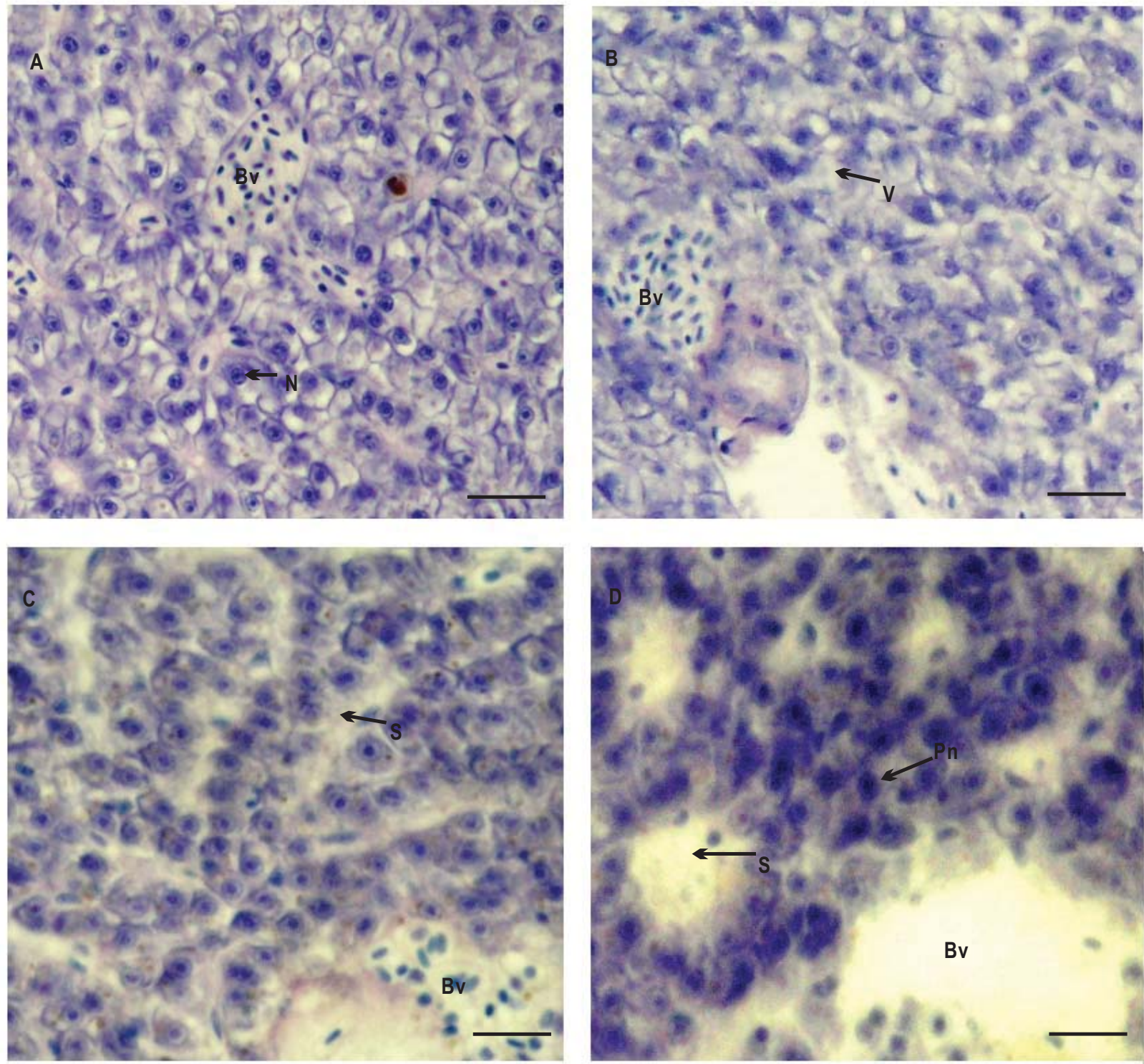

Fig. 3 : Light micrographs of transverse section of the flounder (Paralichthys olivaceus) liver in 0 (control), 5,10 and $15 \mu$ ml $^{-1}$ diethyl phthalate exposure for 14 days (H\&E staining). A: Control liver tissues. N: Hepatocyte nucleus; Bv: Blood vessel. B, C and D: Liver tissues of flounder exposed to 5,10 and $15 \mu \mathrm{g}$ $\mathrm{ml}^{-1}$ diethyl phthalate, respectively. S: Sinusoid; Pn: Pycnotic nucleus; V: Vacuolation. Scale bars: $25 \mu \mathrm{m}$

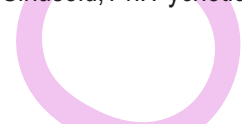

tetrazolium salt to a blue insoluble MTT formazan product by themitochondrial succinic dehydrogenase. After a 24 hrs exposure period, the test medium was replaced by PBS containing $20 \mu 15 \mathrm{mg}$ $\mathrm{ml}^{-1} \mathrm{MTT}$. After incubation for $4 \mathrm{hrs}$ at $20^{\circ} \mathrm{C}$, the solution was carefully removed and the cells were rinsed twice with rapidly. Then $150 \mu$ per well dimethylsulfoxide was added to dissolve the purple formazan crystals that were produced. The absorbance of each well was measured at $490 \mathrm{~nm}$ and the $\mathrm{IC}_{50}$ value was calculated.

All experiments were performed at least three times, and the average absorbance at each dose was calculated and expressed as percentage of absorbance of cells incubated with different doses of diethyl phthalate against control.

DEP acute toxicity to flounders in vivo: The acute toxicity tests were performed according to the semi-static method as described in the OECD guideline for testing of chemicals No. 203 "Test of acute toxicity for fish" (OECD, 1992). Based on the preliminary results, 10 individuals, randomly selected for every group, were exposed to a final concentration of 0 (solvent control), 25, 27.5, $30,32.5$, and $35 \mathrm{~g} \mathrm{~m} \mathrm{~m}^{-1}$ diethyl phthalate in seawater for $96 \mathrm{hrs}$. The seawater was maintained at a constant concentration of 
Table 1 : Acute toxicity of flounder (Paralichthys olivaceus) exposed to different concentrations of diethyl phthalate (DEP) for 96 hrs

\begin{tabular}{llll}
\hline DEP concentration $\left(\mu \mathrm{g} \mathrm{m}^{-1}\right)$ & No. of fish exposed & Mortality $(\%)$ & LC $_{50}$ value $\left(\mu \mathrm{g} \mathrm{m}^{-1}\right)$ \\
\hline 0 & 10 & 0 & \\
25 & 10 & $0 \pm 0$ & \\
27.5 & 10 & $50 \pm 0$ & $31.92 \pm 0.16$ \\
30 & 10 & $50 \pm 2.5$ & \\
32.5 & 10 & $75 \pm 0.5$ & \\
35 & 10 & $100 \pm 0$ & \\
\hline
\end{tabular}
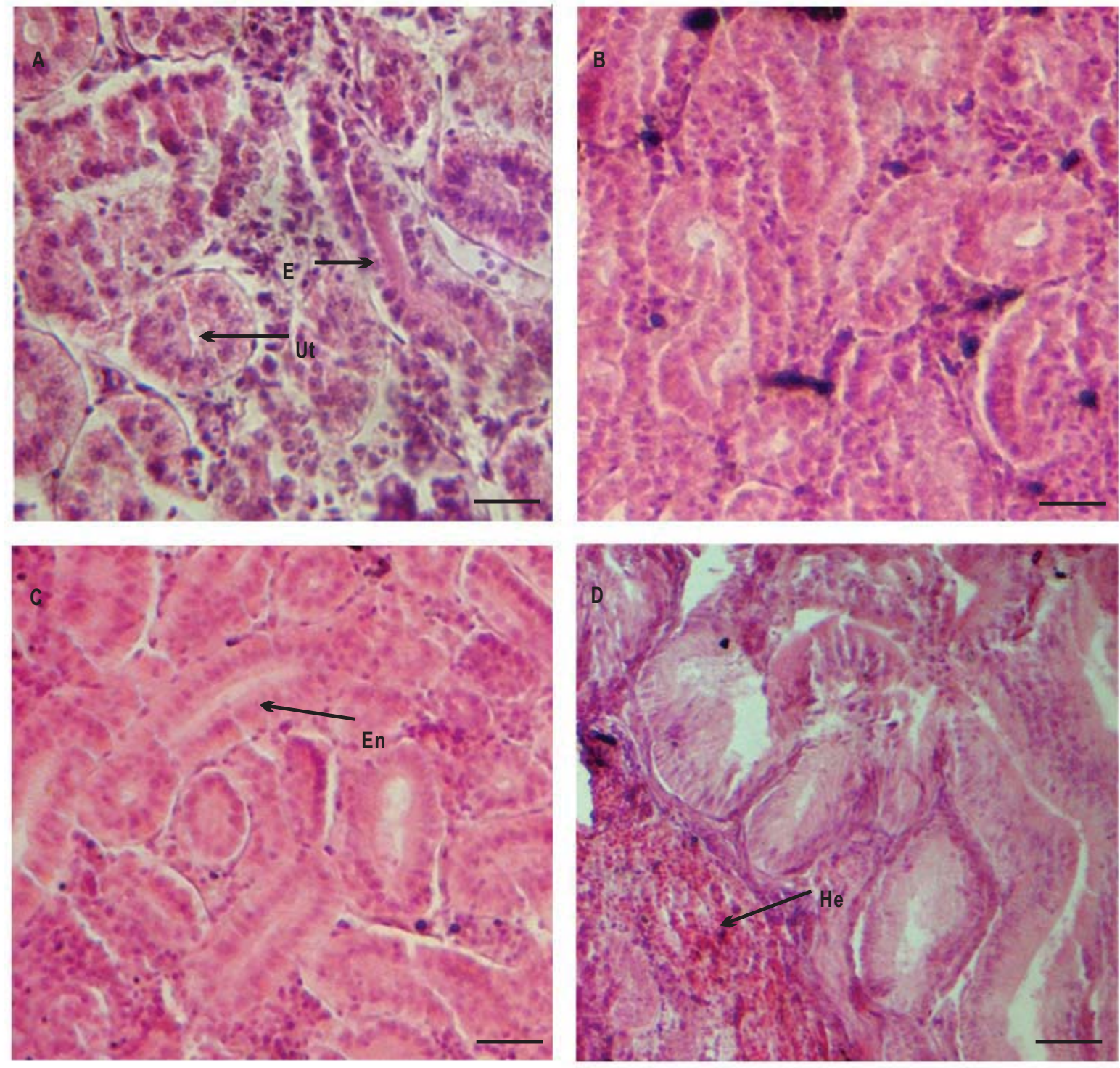

Fig. 4 : Light micrographs of transverse section of Paralichthys olivaceus kidney in 0 (control), 5, 10 and $15 \mu \mathrm{g} \mathrm{m}{ }^{-1}$ diethyl phthalate exposure for 14 days (H\&E staining). A: Control kidney tissues. Ut: Uriniferous tubules; E: Epithelium. B, C and D: Kidney tissues of flounder exposed to 5, 10 and $15 \mu \mathrm{g} \mathrm{ml^{-1 }}$ diethyl phthalate, respectively. En: Epithelium necrosis; He: Hemolytic erythrocytes. Scale bars: $25 \mu \mathrm{m}$ 

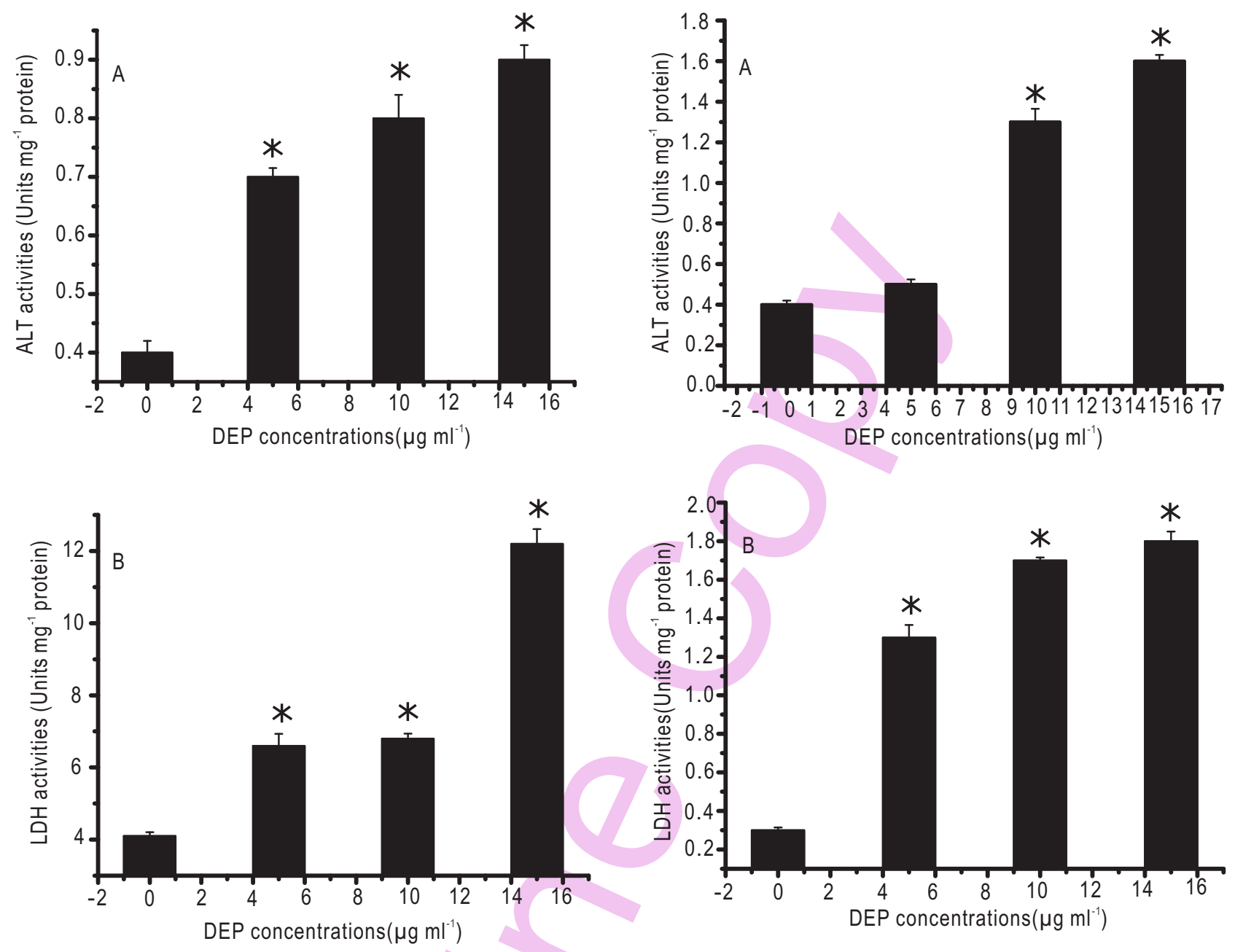

Fig. 5 : Effects of varied concentrations of diethyl phthalate on enzyme activities (ALT and LDH) in liver of Paralichthys olivaceus. Values given as mean \pm S.E. * denotes significant difference from control $(P<0.05)$

Fig. 6 : Effects of varied concentrations of diethyl phthalate on enzyme activities (ALT and LDH) in kidney of Paralichthys olivaceus. Values given as mean \pm S.E. * denotes significant difference from control $(P<0.05)$

diethyl phthalate by changing it at every $24 \mathrm{hr}$. Dead fishes were counted and removed immediately every day. The experiments were repeated three times. The $96 \mathrm{hr}-\mathrm{LC}_{50}$ value was determined using Trimmed Spearman-Karber estimation of $\mathrm{LC}_{50}$. The $95 \%$ confidence limit value was calculated using the Probit method as described by Xiong (2000).

Histopathological examination in flounders : Based on the 96 $\mathrm{hr}-\mathrm{LC}_{50}$ value of diethyl phthalate obtained previously, three sublethal concentrations 5,10 and $15 \mu \mathrm{g} \mathrm{m}^{-1}$ diethyl phthalate were chosen and used for the fish histological examination. Control fish were processed similarly. At the end of 14 days of diethyl phthalate exposure, the fishes from each test group, as well as the control group, were decapitated, and the liver and kidney were dissected out and fixed in Bouin's fixative for $48 \mathrm{hrs}$. They were then washed with running tap water overnight. After

dehydration in graded alcohol series, they were embedded in paraffin and sectioned at $6 \mu \mathrm{m}$. The sections were double stained with hematoxylin and eosin (H\&E), mounted in neutral balsam for observation using an Olympus BX51 (Japan) microscope.

Biochemical parameters analysis in flounders : For biochemical analysis, the control and diethyl phthalate treated fishes were killed by decapitation and livers and kidneys were dissected out and homogenized in cold $0.85 \%$ saline using a glass homogenizer on ice. The final concentrations of the homogenates were adjusted to $10 \%(\mathrm{w} / \mathrm{v})$. The homogenates were centrifuged at $12,000 \mathrm{~g}$ for 15 mins at $4{ }^{\circ} \mathrm{C}$ and used for the assays of enzyme activities. The biochemical parameters [alanine aminotransferase (ALT) and lactate dehydrogenase (LDH)] were determined by an AEROSET automatic biochemical analyzer (Abbott, USA). All experiments were performed in triplicate. 
All data of enzyme activities were evaluated by one-way ANOVA (SPSS V. 13.0 for Windows, tests: least significant difference, Tukey's honestly significant difference). Values were expressed as mean \pm S.E., significance at $p<0.05$.

\section{Results and Discussion}

Acute toxic effects of diethyl phthalate (100 to $800 \mu \mathrm{g} \mathrm{ml}^{-1}$ for $24 \mathrm{hrs}$ ) were evaluated by NR uptake and MTT assays. As shown in Fig. 1, no significant cytotoxicity was noted below $100 \mu \mathrm{g}$ $\mathrm{ml}^{-1}$ diethyl phthalate. Instead, cell viability was excited at low dose. Afterwards, with diethyl phthalate concentrations increasing from $200 \mu \mathrm{g} \mathrm{ml}^{-1}$ to $800 \mathrm{\mu g} \mathrm{ml}^{-1}$, the cytotoxicity was obviously enhanced and showed a concentration-diethyl phthalate endent reduction. By linear regression analysis, the 24 $\mathrm{hr}-\mathrm{IC}_{50}$ (95\% confidence limits) diethyl phthalate values were $536.76 \mu \mathrm{g} \mathrm{m}{ }^{-1}$ and $573.84 \mathrm{\mu g} \mathrm{ml}^{-1}$ for NR and MTT, respectively. The cytotoxicity of diethyl phthalate to FG cells was similar in NR and MTT assays, regardless of the toxic endpoints employed.

Control FG cells are normally epithelioid in morphology as evidence of spindle shapes and attached firmly to the substratum with random orientations (Fig. 2 A). When FG cells were exposed to $100 \mathrm{\mu g} \mathrm{ml}^{-1}$ diethyl phthalate, the cells showed normal morphology and their density was promoted (Fig. 2 B). When treated with $200 \mu \mathrm{g} \mathrm{ml}^{-1}$ diethyl phthalate, the cellular morphology had a little adverse change, as seen by a trend of round shapes compared with the control group (Fig. 2 C). At 400 $\mu \mathrm{g} \mathrm{ml}{ }^{-1}$ diethyl phthalate, the changes of cell morphology were much more obvious even some cells were detached from the cultural substratum (Fig. $2 \mathrm{D}$ ). Further, with 600 and $800 \mu \mathrm{m} \mathrm{ml}^{-1}$ diethyl phthalate treatments for $24 \mathrm{hrs}$, an increasing number of FG cells became swollen, detached from the culture, presented a large number of lipid particles in cytoplasm, and eventually died (Fig. 2E and F). Similar to NR and MTT assays, the morphological change trend of $F G$ cells was also dependent on diethyl phthalate concentrations.

Previous studies have shown that diethyl phthalate has dual effects i.e., low concentration increases cell proliferation, whereas high concentration lead to cell damage and inhibition (Kumar et al., 2014, 2015). Here, the pattern of FG cells with diethyl phthalate exposure has shown similar response as above. It firstly caused cell proliferations at lower concentrations, which is agreed well with the reports about diethyl phthalate's effect on proliferation of MCF-7 and CHO cells (e.g. less than $100 \mu \mathrm{M}$ ) as an estrogenic compound (Hong et al., 2005; Kumar et al., 2014, 2015). With the increase of diethyl phthalate concentrations, the viability of $F G$ cells was inhibited, and cellular morphologies were also adversely altered for $24 \mathrm{hrs}$. These suggested that diethyl phthalate was acutely toxic to FG cells, and FG cell line may be considered to be a primary indicator of cytotoxicity as a bioassay model in vitro. As for diethyl phthalate toxicity mechanism in cell levels, it was concluded the impairments of lysosome and mitochondria in terms of NR uptake and MTT assays. Its physiological defense mechanisms need further investigation in whole fish level, which was performed as follows.

The acute toxicity of diethyl phthalate in flounder fish was evaluated by $96 \mathrm{hr}-\mathrm{LC}_{50}$ in semi-static condition. The behavioral abnormalities of fish exposed to diethyl phthalate $(25,27.5,30$, 32.5 , and $35 \mathrm{\mu g} \mathrm{ml}^{-1}$ ) showed a concentration-dependent pattern in the $96 \mathrm{hr}$ of exposure. When the diethyl phthalate concentration was less than $25 \mathrm{\mu g} \mathrm{ml}^{-1}$, there were no mortality, but sluggishness and lethargic behavior could be observed. When its concentration was increased to $27.5 \mathrm{\mu g} \mathrm{ml}^{-1}$, the exposed fish began to die, and the morality rate was up to $50 \%$. Finally, when diethyl phthalate concentration was $35 \mathrm{\mu g} \mathrm{ml}^{-1}$, all exposed fish died in $96 \mathrm{hr}$ of exposure. From the present investigation, $96 \mathrm{hr}-\mathrm{LC}_{50}$ for flounders was $31.92 \mu \mathrm{g} \mathrm{ml}^{-1}$ (Table 1).

The lethal doses of diethyl phthalate was relatively high (>1 g kg ${ }^{-1}$ in oral or peritoneal administration) for guinea pigs, rats and mice (Api, 2001), however it was moderately toxic to fish (Staples et al., 1997), $48 \mu \mathrm{g} \mathrm{ml}^{-1}$ (96 $\mathrm{hr}^{-\mathrm{LC}_{50}}$ ) to Cyprinus carpio (Barse et al., 2007) and 50 $\mathrm{g} \mathrm{m} \mathrm{ml}^{-1}\left(72 \mathrm{hr}-\mathrm{LC}_{50}\right)$ to Cirrhinus mrigala (Ghorpade et al., 2002). As for Paralichthys olivaceus, the present acute toxicity result $\left(96 \mathrm{hr}-\mathrm{LC}_{50}: 31.92 \mu \mathrm{g} \mathrm{ml}^{-1}\right)$ was similar to the above reported results on aquatic species. This information will be helpful in setting up exposure doses for studying of sublethal responses, including histological lesions and biochemical defense mechanisms.

The $L C_{50}$ is considered as an important reference value for ecotoxicological studies in non-model and model animals for determining exposure doses of pollutants in risk assessment (Won et al., 2016). On the other hand, the $I C_{50}$ value of cells is also a promising estimation data in pollution monitoring due to its rapid and simple bioassay. However, here, the $\mathrm{IC}_{50}$ value was higher about one order of magnitude compared to the $96 \mathrm{hr}-\mathrm{LC}_{50}$, meaning that in vitro cultured fish cells are more tolerant to DEP than living fish. Although the result testified the previous reports that in vitro data are not consistent with in vivo data (Gülden and Seibert, 2005; Yin et al., 2007), the reasons for the higher tolerance of cultured fish cell line than living fish is not clear. One of the main reasons may be that cell lines and living animals belong to different bio-systems, and their action mode are different for in vitro cultured fish cells and living fish.

The structure of normal liver of fish showed polygonal shaped hepatocytes with a densely stained nucleus and congested blood vessels (Fig. $3 \mathrm{~A}$ ). When the fish were treated with diethyl phthalate $5 \mu \mathrm{g} \mathrm{ml}^{-1}$, the liver showed apparent vacuolation in hepatocyte cytoplasm (Fig. 3 B). For $10 \mathrm{~g} \mathrm{~m}^{-1}$ diethyl phthalate treated fish, the structure of livers showed additionally a marked dilation of sinusoid space besides the hepatocyte vacuolation mentioned above (Fig. 3 C). When diethyl phthalate concentration increased to $15 \mu \mathrm{g}$ 
$\mathrm{ml}^{-1}$, severe damages of liver architecture were observed, as evidence of nucleus pyknosis, hepatic sinusoid disorder accompanied with cloudy swelling, and degradation of cell membrane (Fig. $3 \mathrm{D}$ ). The effects were similar to other xenobiotics exposed fishes (Channa punctata Bloch) (Tabassum et al., 2016).

It is a quite well-known fact that drug toxicity is rarely limited only to one particular organ. As for the flounder kidneys, the control section showed normal structures of uriniferous tubules, in which tubular epithelial cells were ranged in order with clear nuclei (Fig. $4 \mathrm{~A}$ ). When fish was treated with $5 \mu \mathrm{g} \mathrm{ml}^{-1}$ diethyl phthalate, it was seen that epithelium boundary was obscured and the nuclei were also unapparent in uriniferous tubules, which indicated the beginning of a necrosis step (Fig. 4 B). When fish were exposed to higher concentrations $\left(10 \mu \mathrm{g} \mathrm{ml}^{-1}\right.$ and $\left.15 \mu \mathrm{g} \mathrm{ml}^{-1}\right)$, a more severe deterioration trend was observed including degradation of tubular epithelial cells and multiple hemorrhages in kidneys (Fig. $4 \mathrm{C}$ and $\mathrm{D}$ ). The renal histoarchitecture suggested that diethyl phthalate caused renal cellular damage and necrosis.

It was reported that significant changes in histological structure are associated with alterations in biochemical parameters (Haimanti et al., 2008; Husak et al., 2014). To investigate if these histopathological alterations, can cause dysfunction of these tissues of flounders in the study, biochemical parameters were evaluated at same diethyl phthalate-exposed concentrations.

As shown in Fig. 5 the activities of ALT and LDH increased significantly in the liver of flounders exposed to all diethyl phthalate concentrations $(p<0.05)$. The ALT levels $75 \%, 100 \%$ and $125 \%$ increase in the treatment groups $\left.(5,10 \text { and } 15 \mu \mathrm{g} \mathrm{ml})^{-1}\right)$, respectively (Fig. 5A). ALT is clinically an important metabolic transaminase. Increased ALT levels indicated that diethyl phthalate stimulated transaminase activity due to the toxic injury caused by diethyl phthalate, which enhance tissue repair through protein turnover and amino acid metabolism. (Ghorpade et al., 2002; Jeon et al., 2013). LDH levels also showed a dramatic rise of $60 \%, 66 \%$ and $197 \%$ increase in 5,10 and $15 \mu \mathrm{g} \mathrm{ml}{ }^{-1}$ diethyl phthalate concentration, respectively (Fig. 5B). The elevated activity of LDH in response to diethyl phthalate indicated an increase in anaerobic respiratory activity and production of more lactate for completion of metabolic process (Tripathi and Singh, 2013). In a word, the elevated levels of ALT and LDH demonstrated the metabolism and detoxification capacity was enhanced in liver tissue because of exposure of diethyl phthalate.

ALT and LDH enzyme activities were enhanced to various extents, especially at 10 and $15 \mu \mathrm{g} \mathrm{m} \mathrm{l}^{-1} \mathrm{DEP}$, showing a significant rise (ALT: $225 \%$ and $300 \%$; LDH: $466 \%$ and $500 \%$, $)(p<0.05)$. Kidney is reported as a major route for the excretion of xenobiotics. Fish kidney is a primary organ to be affected by toxicants in the aquatic environment (Thophon et al., 2003;
Qureshi et al., 2016). In the study, the up-regulation of enzyme activities (ALT and LDH) indicated metabolic change and damage response in kidney tissue. Hence, intoxication with DEP may potentially induce histological changes and modify the biochemical parameters in fish kidney. The pathological examinations and biochemical analysis in kidneys might be expected to be good indication of the study of DEP action mechanisms.

In conclusion, the study demonstrated that diethyl phthalate is a toxic substance both for fish and its cell line in vitro as well as in vivo. The cultured FG cells are applicable for a rapid estimation for diethyl phthalate acute toxicity. The experiment of in vivo toxicity of diethyl phthalate is a robust analytical method for studying diethyl phthalate toxic mechanism.

\section{Acknowledgments}

The work was supported by the projects from Hebei Education Department (No. ZD2015119) and Department of Science and Technology of Hebei province (No. 12276712D) in China.

\section{References}

Api,A.M.: Toxicological profile of diethyl phthalate: a vehicle for fragrance and cosmetic ingredients. Food Chem. Toxicol., 39, 97-108 (2001).

Barse, A.V., T. Chakrabarti, T.K. Ghosh, A.K. Pal and S.B. Jadhao: Endocrine disruption and metabolic changes following exposure of Cyprinus carpio to diethyl phthalate. Pestic. Biochem. Phys., 88, 36-42 (2007).

Borenfreund, E. and J.A. Puerner: Toxicity determined in vitro by morphological alterations and neutral red absorption. Toxicol. Lett., 24, 119-124 (1985).

Borenfreund, E., H. Babich and N. Martin-Alguacil: Comparison of two in vitro cytotoxicity assays: The neutral red (NR) and tetrozolium (MTT) tests. Toxicol. in Vitro, 2, 1-6 (1988).

Ghorpade, N., V. Mehta, M. Khare, P. Sinkar, S. Krishnan and C.V. Rao: Toxicity study of diethyl phthalate on freshwater fish Cirrhina mrigala. Ecotoxicol. Environ. Saf., 53, 255-258 (2002).

Giulivo, M., M.L. de Alda, E. Capri and D. Barceló: Human exposure to endocrine disrupting compounds: Their role in reproductive systems, metabolic syndrome and breast cancer. Environ. Res., 151, 251-264 (2016).

Gülden, M. and H. Seibert: Impact of bioavailability on the correlation between in vitro cytotoxic and in vivo acute fish toxic concentrations of chemicals. Aquat. Toxicol., 72, 327-337 (2005).

Haimanti, B., Q. Xiao and L. Lun: Toxicity studies of nonylphenol on rosy barb (Puntius conchonious): A biochemical and histopathological evaluation. Tissue Cell, 40, 243-249 (2008).

Hong, E.J., Y.K. Ji, K.C. Choi, N. Manabe and E.B. Jeung: Conflict of estrogenic activity by various phthalates between in vitro and in vivo model related to the expression of Calbindin-D9k. J. Reprod Dev., 51, 253-263 (2005).

Husak, V.V., N.M. Mosiichuk, I.V. Maksymiv, I.Y. Sluchyk, J.M. Storey, K.B. Storey and V.I. Lushchak: Histopathological and biochemical changes in goldfish kidney due to exposure to the herbicide Sencor may be related to induction of oxidative stress. Aquat. Toxicol., 155, 181-189 (2014).

Jeon, Y.M., W.J. Kim and M.Y. Lee: Studies on liver damage induced by 
nanosized-titanium dioxide in mouse. J. Environ. Biol., 34, 283287 (2013).

Kang, J.C., J.H. Jee, J.G. Koo, Y.H. Keum, S.G. Jo and K.H. Park: Antioxidative status and hepatic enzymes following acute administration of diethyl phthalate in olive flounder Paralichthys olivaceus, a marine culture fish. Ecotoxicol. Environ. Saf., 73, 1449-1455 (2010).

Kim, S.M., J.A. Yoo, J.M. Baek and K.H. Cho: Diethyl phthalate exposure is associated with embryonic toxicity, fatty liver changes, and hypolipidemia via impairment of lipoprotein functions. Toxicol. in Vitro, 30, 383-393 (2015).

Kumar, N., S. Sharan, S. Srivastava and P. Roy: Assessment of estrogenic potential of diethyl phthalate in female reproductive system involving both genomic and non-genomic actions. Reprod. Toxicol., 49, 12-26 (2014).

Kumar, N., S. Srivastava and P. Roy: Impact of low molecular weight phthalates in inducing reproductive 4 malfunctions of male mice: Special emphasis on Sertoli cell functions. Gen. Comp. Endocr., 215, $36-50$ (2015).

Leitz, J., T. Kuballa, J. Rehm and D.W. Lachenmeier: Chemical analysis and risk assessment of diethyl phthalate in alcoholic beverages with special regard to unrecorded alcohol. PLoS One, 4, 17(2009).

Mankidy, R., S. Wiseman, H. Ma and J.P. Giesya: Biological impact of phthalates. Toxicol. Lett., 217, 50-58 (2013).

Na, N., H. Guo, S. Zhang, Z. Li and L. Yin: In vitro and in vivo acute toxicity of fenpyroximate to flounder Paralichthys olivaceus and its gill cell line FG. Aquat. Toxicol., 92, 76-85 (2009).

Nakayama, K., S.I. Kitamura, Y. Murakami, J.Y. Song, S.J. Jung, M.J. Oh, $\mathrm{H}$. Iwata and S. Tanabe: Toxicogenomic analysis of immune systemrelated genes in Japanese flounder (Paralichthys olivaceus) exposed to heavy oil. Mar. Pollut. Bull., 57, 445-452 (2008).

OECD: Guideline for testing of chemicals No. 203 "Fish, Acute toxicity test". $3^{\text {rd }}$ Edn., United Kingdom (1992).

Page, B.D. and G.M. Lacroix: The occurrence of phthalate esters and di2-ethylhexyl adipate plasticizers in Canadian packaging and food sampled in 1985-1989: A survey. Food Addit. Contam., 12, 129151 (1995).

Pandey, M.R. and H. Guo: Evaluation of cytotoxicity, genotoxicity and embryotoxicity of insecticide propoxur using flounder gill (FG) cells and zebrafish embryos. Toxicol. in Vitro, 28, 340-353 (2014).

Qureshi, I.Z., A. Bibi, S. Shahid and M. Ghazanfar: Exposure to subacute doses of fipronil and buprofezin in combination or alone induces biochemical, hematological, histopathological and genotoxic damage in common carp (Cyprinus carpio L.). Aquat. Toxicol., 179, 103-114 (2016).

Staples, C.A., T.F. Parkerton and D.R. Peterson: A risk assessment of selected phthalate esters in North American and Western European surface waters. Chemosphere, 40, 885-891 (2000).

Staples, C.A., W.J. Adams, T.F. Parkerton, J.W. Gorsuch, G.R. Biddinger and K.H. Reinhard: Aquatic toxicity of eighteen phthalate esters. Environ. Toxicol. Chem., 16, 875-891 (1997).

Tabassum, H., M. Ashafaq, J. Khan, M.Z. Shah, S. Raisuddin and S. Parvez: Short term exposure of pendimethalin induces biochemical and histological perturbations in liver, kidney and gill of freshwater fish. Ecol. Indic., 63, 29-36 (2016).

Thophon, S., M. Kruatrachue, E.S. Upatham, P. Pokethitiyook, S. Sahaphong and S. Jaritkhuan: Histopathological alterations of white seabass, Lates calcarifer, in acute and subchronic cadmium exposure. Environ. Pollut., 121, 307-320 (2003).

Tong, S.L., H. Li and H.Z. Miao: The establishment and partial characterization of a continuous fish cell line FG-9307 from the gill of flounder Paralichthys olivaceus. Aquaculture, 156, 327-333 (1997).

Tripathi, G. and H. Singh: Impact of alphamethrin on biochemical parameters of Channa punctatus. J. Environ. Biol., 34, 227-230 (2013).

Vinay, T.N., C.S. Park, H.Y. Kim and S.J. Jung: Toxicity and dose determination of quillaja saponin, aluminum hydroxide and squalene in olive flounder (Paralichthys olivaceus). Vet. Immunol. Immunop., 158, 73-85 (2014).

Won, E.J., J. Han, A. Hagiwara, S. Oda, H. Mitani and J.S. Lee: Acute toxicity of gamma radiation to the monogonont rotifer Brachionus koreanus. Bull. Environ. Contam. Toxicol., 97, 387-391 (2016).

Xiao, Q., D. Li and H. Liu:A flounder (Paralichthys olivaceus) gill cell line as in vitro acute assay system of nonylphenol cytotoxicity. Environ. Monit. Assess., 175, 315-319 (2011).

Xiao, Q., S.C. Zhang, H.R. Guo, F.Su and Y.Y. Xu: Nonylphenol causes decrease in antioxidant enzyme activities, increase in $\mathrm{O}^{2-}$ content, and alteration in ultrastructures of FG cells, a flounder (Paralichthy olivaceus) gill cell line. Toxicol. Mech. Methods, 17, 127-134 (2007).

Xiong, Z.T.: Environmental Biology. Wuhan University Press, Wuhan, pp.134-137 (2000).

Yin, L.C., H.R. Guo, S.C. Zhang and J. Wang: Study on the acute toxicity and genotoxicity of herbicide butachlor in flounder, Paralichihys olivaceus, and flounder gill (FG) cells. J. Ocean Univ., 37, 167-171 (2007). 